\title{
Identification by Molecular Docking of Homoisoflavones from Leopoldia comosa as Ligands of Estrogen Receptors
}

\author{
Fedora Grande ${ }^{1, *(\mathbb{D})}$, Bruno Rizzuti ${ }^{2, *}(\mathbb{D})$, Maria A. Occhiuzzi ${ }^{1}$, Giuseppina Ioele ${ }^{1}$, \\ Teresa Casacchia ${ }^{1}$, Fabrizio Gelmini ${ }^{3}$, Rita Guzzi ${ }^{2,4}$, Antonio Garofalo ${ }^{1}$ and Giancarlo Statti ${ }^{1}$ \\ 1 Department of Pharmacy, Health and Nutritional Sciences, University of Calabria, Ampl. Polifunzionale, \\ Via P. Bucci, 87036 Rende (CS), Italy; mariaantonietta.occhiuzzi@unical.it (M.A.O.); \\ giuseppina.ioele@unical.it (G.I.); teresa.casacchia@unical.it (T.C.); antonio.garofalo@unical.it (A.G.); \\ giancarlo.statti@unical.it (G.S.) \\ 2 CNR-NANOTEC, Licryl-UOS Cosenza and CEMIF.Cal, Department of Physics, University of Calabria, \\ Via P. Bucci, 87036 Rende (CS), Italy; rita.guzzi@fis.unical.it \\ 3 Department of Environmental Science and Policy-ESP, University of Milan, Via Celoria 2, 20133 Milan, Italy; \\ fabrizio.gelmini@unimi.it \\ 4 Department of Physics, University of Calabria, Via P. Bucci, 87036 Rende (CS), Italy \\ * Correspondence: fedora.grande@unical.it (F.G.); bruno.rizzuti@cnr.it (B.R.); Tel.: +39-098-449-3019 (F.G.); \\ +39-098-449-6078 (B.R.)
}

Academic Editors: Jean Jacques Vanden Eynde, Annie Mayence and Tien L. Huang

Received: 21 March 2018; Accepted: 10 April 2018; Published: 12 April 2018

\begin{abstract}
The physiological responses to estrogen hormones are mediated within specific tissues by at least two distinct receptors, ER $\alpha$ and ER $\beta$. Several natural and synthetic molecules show activity by interacting with these proteins. In particular, a number of vegetal compounds known as phytoestrogens shows estrogenic or anti-estrogenic activity. The majority of these compounds belongs to the isoflavones family and the most representative one, genistein, shows anti-proliferative effects on various hormone-sensitive cancer cells, including breast, ovarian and prostate cancer. In this work we describe the identification of structurally related homoisoflavones isolated from Leopoldia comosa (L.) Parl. (L. comosa), a perennial bulbous plant, potentially useful as hormonal substitutes or complements in cancer treatments. Two of these compounds have been selected as potential ligands of estrogen receptors (ERs) and the interaction with both isoforms of estrogen receptors have been investigated through molecular docking on their crystallographic structures. The results provide evidence of the binding of these compounds to the target receptors and their interactions with key residues of the active sites of the two proteins, and thus they could represent suitable leads for the development of novel tools for the dissection of ER signaling and the development of new pharmacological treatments in hormone-sensitive cancers.
\end{abstract}

Keywords: natural compounds; molecular docking; estrogen receptors; ligand interactions

\section{Introduction}

The estrogen receptors (ERs), members of the nuclear receptor family, are ligand-inducible intracellular transcription factors and are involved in the regulation of several physiological processes, including cell growth, survival and differentiation [1-3]. In mammals, cellular responses to estrogens are mainly mediated by two different estrogen receptor subtypes, ER $\alpha$ and $E R \beta$, which exhibit variable expression and distribution levels, as well as distinct signaling responses. ER $\alpha$ is predominantly expressed in female reproductive organs, breast, kidney, bone, white adipose tissue and liver, whereas 
$\mathrm{ER} \beta$ has been found in several tissues of both male and female bodies including the central nervous system, colon, lung, kidney, male reproductive organs, and cardiovascular and immune systems. As members of the nuclear receptor protein family, ERs are located in the nucleus, even if they are also present in the cytoplasm and mitochondria [4].

The activities of ERs are modulated by a variety of natural and synthetic ligands. The activated ligand-ER homodimer complex binds to specific DNA sequences EREs (estrogen-response elements) and regulates transcription activity throughout interactions with specific transcription modulators. In some cases, $\mathrm{ER} \alpha$ and $\mathrm{ER} \beta$ could form heterodimers, and experimental evidence suggests that in this form they can induce activation of target genes that are different from those induced by homodimers [5-8].

Extensive data [9-13] have been recently published on the ER structures, their intra- and inter-molecular interactions, and related post-translational modifications. These proteins are the natural target of estrogens, such as $17 \beta$-estradiol (E) (Figure 1), which are steroid hormones biosynthesized initially from cholesterol. ER $\alpha$ is expressed only in a low fraction of cells in healthy breast epithelium, whereas its expression significantly increases (up to $80 \%$ of cells) in breast cancer [14]. On the other hand, more than $80 \%$ of normal breast epithelial cells express $E R \beta$, whereas its presence is reduced or completely suppressed during breast cancer emergence and progression [15]. Accordingly, anti-hormonal therapy is commonly adopted for the treatment of breast cancer in patients that show an over-expression of such a receptor.

A number of chemical compounds derived from plants, known as phytoestrogens, demonstrates the ability to bind to the estrogen receptors, producing estrogenic or anti-estrogenic activity. Their potential anti-proliferative effects could be useful for the formulation of nutraceuticals or pharmaceutics. Tamoxifen (TX), a selective estrogen-receptor modulator (SERM), is nowadays the most effective and widely used anti-estrogen drug used for this purpose. However, several patients treated with TX develop a rapid onset of resistance [4]. Thus, the identification of novel anti-estrogen compounds able to overcome resistance onset is still demanding.

Several natural compounds have shown interesting estrogenic activity, the majority of them belonging to the isoflavones family. The most representative one, genistein (G) (Figure 1), has shown anti-proliferative effects on various hormone-sensitive cancer cells including breast, ovarian and prostate cells [16-18]. The structure of $\mathbf{G}$ has many points of similarity to $\mathbf{E}$, and this could explain its capability in binding the estrogen receptors within the same active site.

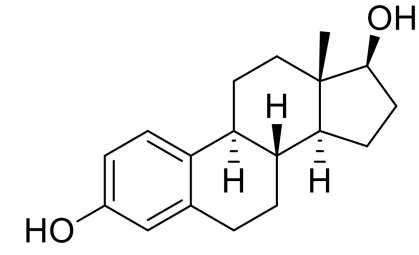

E<smiles>O=c1c(-c2ccc(O)cc2)coc2cc(O)cc(O)c12</smiles>

G

Figure 1. Structures of $17 \beta$-estradiol (E) and genistein (G).

The increasing interest of the scientific community in the health benefits of the Mediterranean diet led us to investigate the estrogenic activity of homoisoflavones structurally related to $G$ and isolated from Leopoldia comosa (L.) Parl., (ex Muscari), a perennial bulbous plant that is endemic in southern Italy. A number of ethnobotanical investigations demonstrated a wide use of L. comosa bulbs in traditional cooking recipes and in the formulation of remedies useful for the treatment of toothache and skin spots [19-21]. Earlier studies demonstrated the anti-oxidant, anti-inflammatory, diuretic, and anti-obesity properties of L. comosa extracts mainly due to the considerable presence of homoisoflavones [22-25]. These natural anti-oxidants were also found endowed with cytotoxic properties in a panel of in vitro human cancer models at low micromolar-range concentrations [22,26]. 
This study describes the identification of two homoisoflavones isolated from L. comosa as ER ligands, thus useful as hormonal substitutes or complements in breast cancer treatments. Molecular docking studies on the crystallographic structures of ERs have been carried out to investigate the binding mode of these homoisoflavones on both receptors. The results indicate that the two novel molecules can effectively bind ERs in the same binding site of both E and G. Furthermore, they show a greater conformational adaptability in their binding geometry compared to G, within both $\mathrm{ER} \alpha$ and $\mathrm{ER} \beta$, thus proving that they could be of interest for the development of selective agents useful in the treatment of hormone-sensitive cancers.

\section{Results and Discussion}

\subsection{Homoisoflavones from Leopoldia comosa}

Several phenolic compounds based on a 3-benzylchroman-4-one skeleton and termed homoisoflavones have been isolated from various genres of the Hyacinthaceae plants family [27]. These compounds are generally classified in three small groups: 3-benzyl-4-cromanones, 3-benzylidene-4-cromanones and scillascylinoid homoisoflavones [28,29]. Although these compounds are considered as a sub-class of the extensively studied flavonoids, some steps in their biosynthetic pathways still need to be elucidated and, therefore, further studies are necessary to fully establish their chemical origin and biological properties [30]. Homoisoflavonoids are biosynthesized from cinnamic acid derivatives along with malonyl-CoA sub-units through the shikimato route by following the polyketide pathway. In a following step, phenylalanine is formed from prephenate and leads to a C-4, C-3, C-9 backbone, to which another ring is added from the acetate/mevalonate pathway [31]. Geopedological aspects and agronomic techniques have a significant influence on the polyphenol content and related biological activity of the plant extracts [32]. In the genus L., two different classes of homoisoflavonoids have been identified: 3-benzylchroman-4-one containing compounds and scillascillin derivatives (Figure 2).<smiles>O=C1c2ccccc2OCC1Cc1ccccc1</smiles>

A<smiles>O=C1c2c(O)cc(O)cc2OCC12Cc1ccc3c(c12)OCO3</smiles>

B

Figure 2. Structures of 3-benzylchroman-4-one (A) and scillascillin (B).

In this study, bulbs of L. comosa were collected in the fields of the Sila Massif, Calabria, southern Italy. The bulbs were opportunely stored in a cool and dry environment and successively separated from roots and soil residues. The bulbs were then subjected to extraction with a water/ethanol mixture. The total phenol and the total flavonoid content of the whole extract was determined using the Folin-Ciocalteu reagent and chlorogenic acid as standard [33] and with the $\mathrm{AlCl}_{3}$ colorimetric method [34], respectively, following known procedures [23]. The phytochemical identification of homoisoflavones present in the total extract of the bulbs was conducted through semi-preparative high-performance liquid chromatography (HPLC) and gas chromatography-mass spectrometry (GC-MS) (Figure 3), after functionalization of the whole extract. Comparison of the results obtained with the two applied techniques allowed the recognition of two compounds, N1 (5,7-dihydroxy-3-(4-hydroxy-3-methoxybenzyl)chroman-4-one) and N2 (5,7-dihydroxy-3-(4-hydroxybenzyl)-8-methoxychroman-4-one), belonging to the 3-benzylchroman4-one class (Figure 4). 

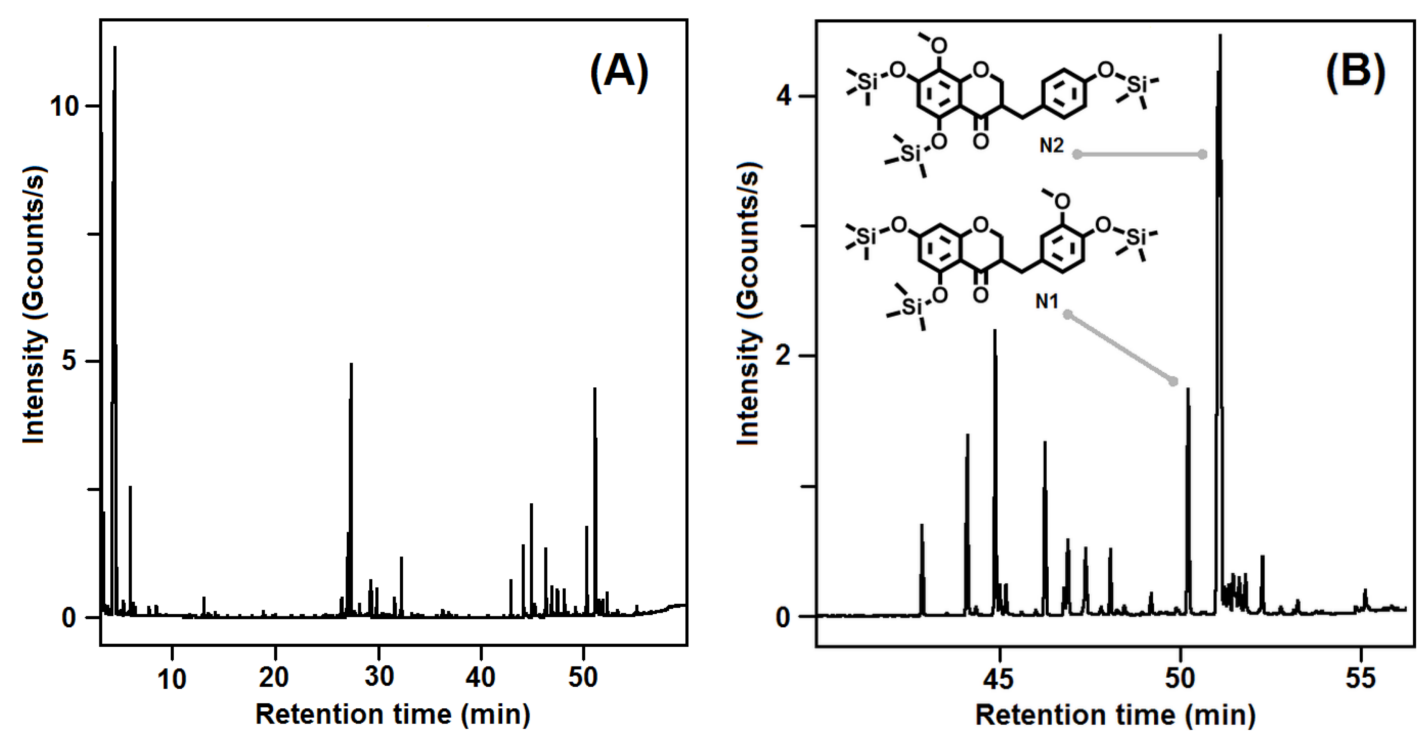

Figure 3. Gas chromatography-mass spectrometry (GC-MS) analysis of the hydroalcoholic extract of L. comosa bulbs: (A) chromatographic profile (total ion current, TIC); (B) detail of the chromatogram including indication of the peaks of the two silyl-functionalized homoisoflavones N1 and N2.<smiles>COc1cc(CC2COc3cc(O)cc(O)c3C2=O)ccc1O</smiles>

N1<smiles>COc1c(O)cc(O)c2c1OC[C@H](Cc1ccc(O)cc1)C2=O</smiles>

N2

Figure 4. Structures of the identified homoisoflavones N1 and N2.

\subsection{Binding to Estrogen Receptor (ER) Proteins}

Molecular docking is a useful technique to investigate the association of ligands to a target protein, and it has already been applied to elucidate details of the binding properties of ERs [35-38]. Accordingly, after identification of the two naturally occurring homoisoflavones N1 and N2, molecular docking studies were performed to investigate their binding to the active site of both ERs. To this aim, the binding modes and affinities of these two compounds were compared to those obtained for known ligands of ERs, E and G. In particular, we investigated whether the replacement of the appended substituted phenyl ring of $\mathbf{G}$ with a substituted benzyl of $\mathbf{N} \mathbf{1}$ and $\mathbf{N} \mathbf{2}$ was consistent with a retained affinity within the active site of the receptors. Such an alteration confers a higher degree of flexibility to the whole molecular asset and, on the other hand, keeps aromatic moieties slightly farther from each other with respect to their position in G. As a result, the calculated distance between 3- and 17-OH of $\mathbf{E}$ and the corresponding groups in $\mathbf{G}$ (7- and phenolic-OH) remains almost unchanged between 7-OH and phenolic-OH in N1 and N2. Furthermore, the presence of a stereocenter in both compounds (Figure 4) led to enantiomers, which could differently accommodate into the receptor's active site. In order to evaluate the influence of chirality to the interaction with the key residues of the active site of ERs, molecular docking studies were performed on both enantiomers of each compound.

The availability of several ER models allowed us to pursue a structure-based approach to characterize the interaction of isolated homoisoflavones within the ligand-binding pocket of 
the receptors. The ligands were docked into the crystallographic structures of both ER $\alpha$ and ER $\beta$, obtained from the Protein Data Bank (PDB) [39]. The crystallographic structures selected for this study include three $E R \alpha-E$ and two ER $\alpha-G$ complexes, as well as one ER $\beta-E$ and two ER $\beta-G$ complexes. In some of these complexes the receptor is represented as a monomer (1X7R [40] and 2OCF [41] for $\mathrm{ER} \alpha$, and 1QKM [42] for ER $\beta$ ) and in other as homodimer (2QA8 [43], 1A52 [44] and 1GWR [45] for $\mathrm{ER} \alpha$, and 1X7J [40] and 5TOA [46] for ER $\beta$ ).

In a first step, the crystallographic structures of both ERs in complex with $\mathbf{E}$ and $\mathbf{G}$ were considered, and their shape complementarity, hydrogen-bonding network, and van der Waals clashes with the ligands were thoroughly analyzed. The crystal structures of the receptors showed the presence of a compact ellipsoid cavity, where ligands are surrounded by a hydrophobic environment. Within this pocket, $\mathrm{OH}$ groups of $\mathbf{E}$ at positions 3 and 17, as well as the hydroxyl groups of $\mathbf{G}$ at position 7 and phenolic-OH and a further $\mathrm{OH}$ group at position 5, play an important role in orienting the ligand within the active site.

For evaluating the binding affinity of the ligands in their anchoring location, the scoring function of AutoDock Vina [47] was used with a re-docking of the crystallographic binding poses in their exact crystallographic position, without performing any search within the protein volume. The resulting binding energies, reported in Table 2, ranged from -9.4 to $-10.0 \mathrm{kcal} / \mathrm{mol}$ for $\mathbf{E}(-9.7 \mathrm{kcal} / \mathrm{mol}$ on average), and from -7.8 to $-9.6 \mathrm{kcal} / \mathrm{mol}$ for $\mathrm{G}(-8.9 \mathrm{kcal} / \mathrm{mol}$ on average). These findings point to a preference in the binding of $\mathbf{E}$ compared to $\mathbf{G}$, although the variability obtained in the binding values of the latter is higher (standard deviations were 0.2 and $0.7 \mathrm{kcal} / \mathrm{mol}$ for $\mathbf{E}$ and $\mathbf{G}$, respectively). In contrast, no significant differences were found between ER $\alpha$ and ER $\beta$ in the binding values for these two ligands.

We also tested the ability of the docking engine to identify the ligand-binding site in a blind search performed on the protein volume. To this end, docking simulations were carried out with the unliganded receptors (i.e., the protein structures with the ligand taken away), considering again the binding of the two crystallographic ligands. As shown in Figures 5 and 6, both E and G were found to bind within the ER site in the same position determined in crystallography, with a root mean square displacement $\leq 1 \AA$. The complexes obtained were further refined in an energy minimization procedure by using a molecular mechanics protocol [48] to mimic the refinement process commonly adopted in crystallography $[49,50]$ and for a more direct comparison with the protocol that we later used for testing the binding of our compounds (see below).

The affinities obtained for $\mathbf{E}$ and $\mathbf{G}$ (see Table 2) were on average -9.8 and $-8.8 \mathrm{kcal} / \mathrm{mol}$, respectively, confirming a preference in the binding of the former ligand by $1 \mathrm{kcal} / \mathrm{mol}$. The deviation in the variability of the binding energies were $0.3 \mathrm{kcal} / \mathrm{mol}$ for both ligands, proving that the energetic preference in the binding of $\mathbf{E}$ is significant. As in the case of the re-docking of the crystallographic ligands without performing any search, differences between ER $\alpha$ and ER $\beta$ in the binding of these ligands were found to be negligible. We also noted that, although the binding energies found with the two procedures (i.e., either re-docking the binding modes in their exact crystallographic position or performing a blind search followed by an energy minimization) were not identical in general, their average value and dispersion were the same. Thus, the values obtained for $\mathbf{E}$ and $\mathbf{G}$, reported above, can be considered as references to compare the binding affinity of other compounds to the same receptors. 


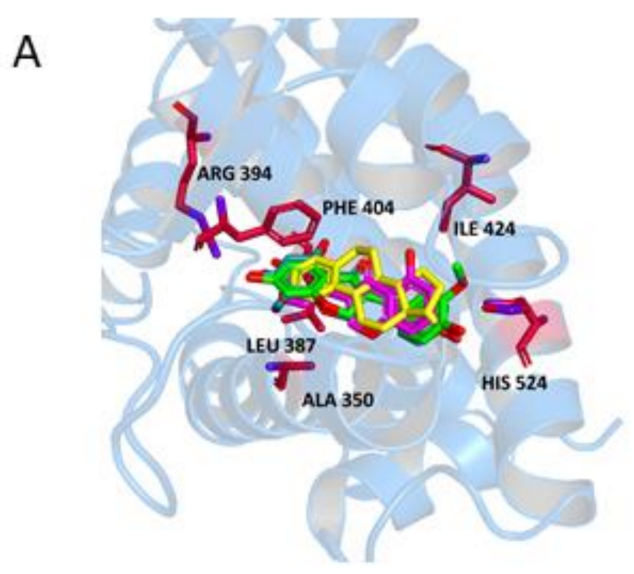

B

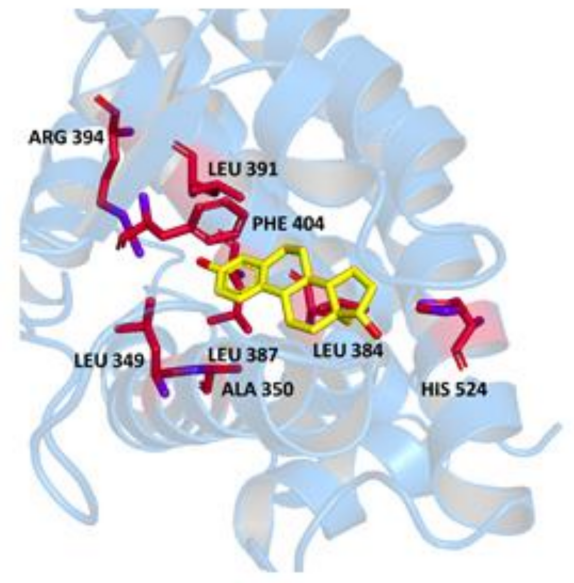

D

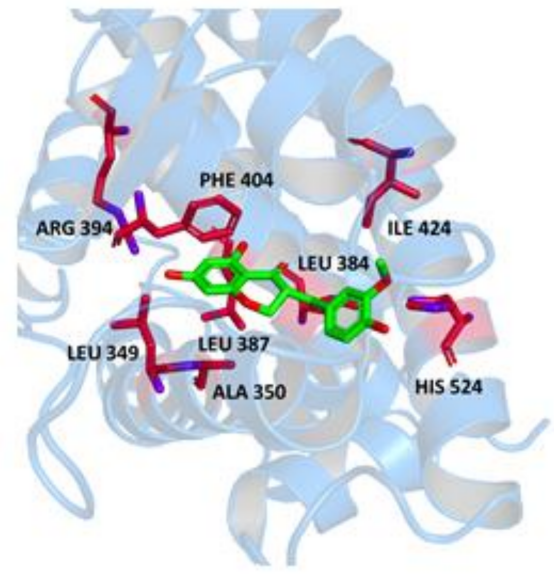

C

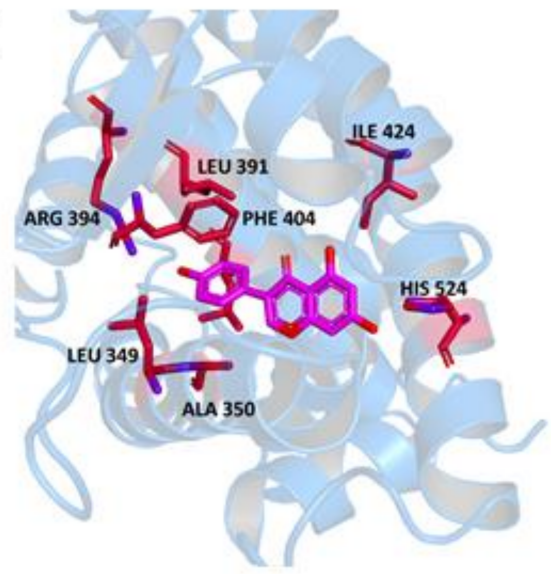

$\mathrm{E}$

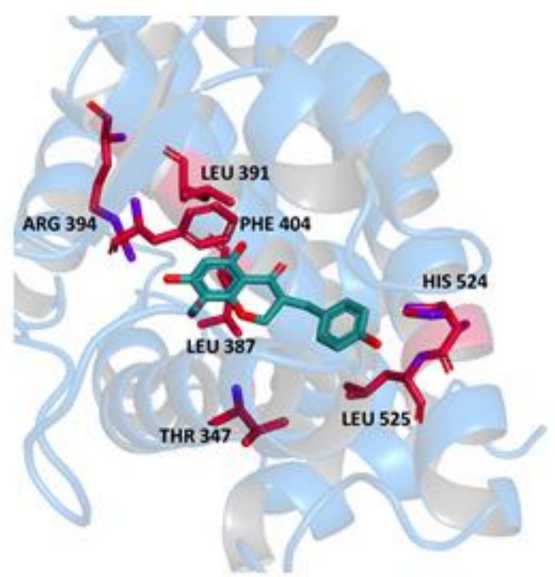

Figure 5. Ligand-binding pocket of the active site of $E R \alpha$; ribbons representing protein structural elements are also shown. (A) Superimposed binding modes of all the four ligands: E (yellow), G (magenta), (R)-N1 (green), and (R)-N2 (cyan); the key residues are also indicated in the specific binding mode of (B) E; (C) G; (D) (R)-N1; and (E) (R)-N2. 
A

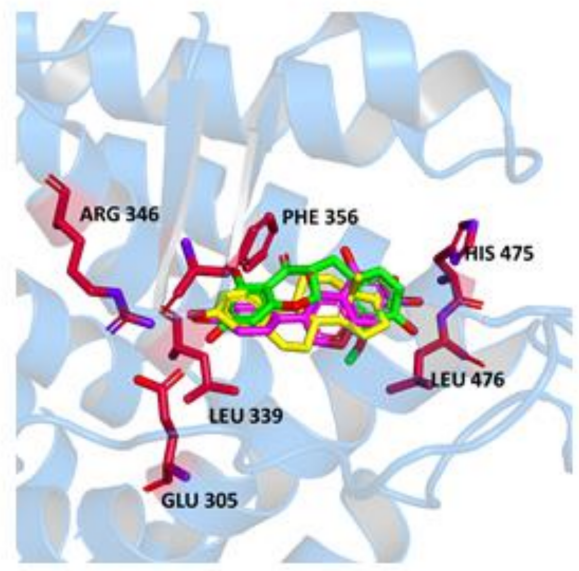

B

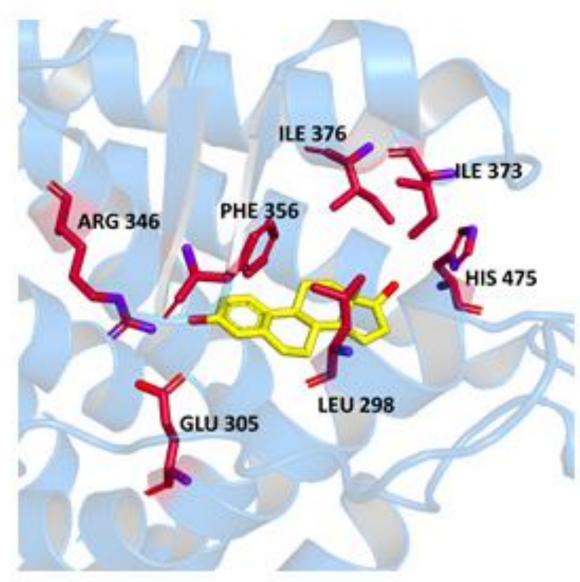

D

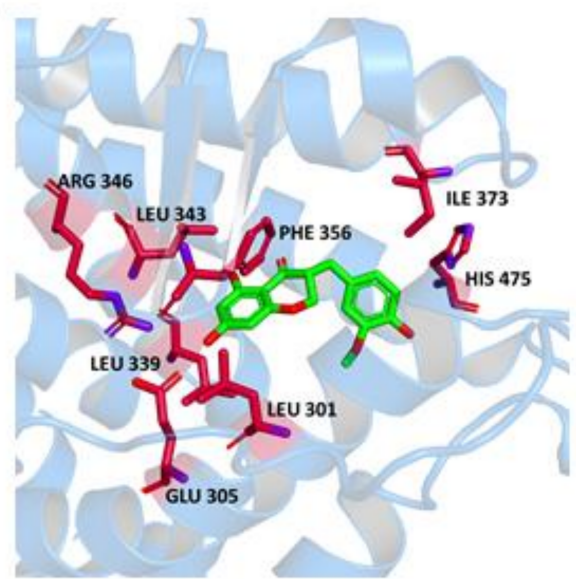

C

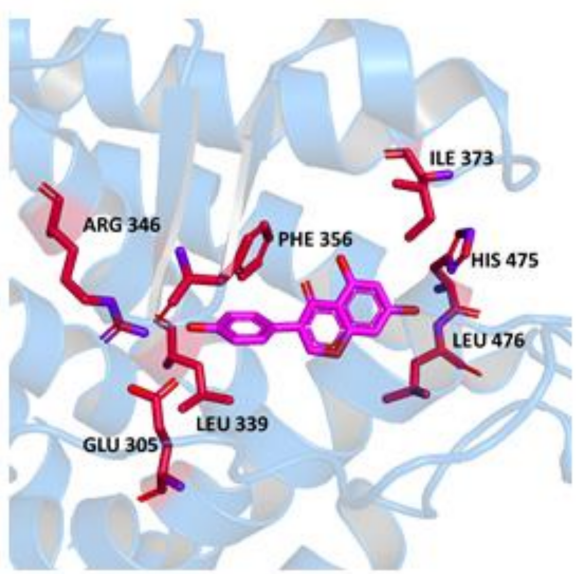

$E$

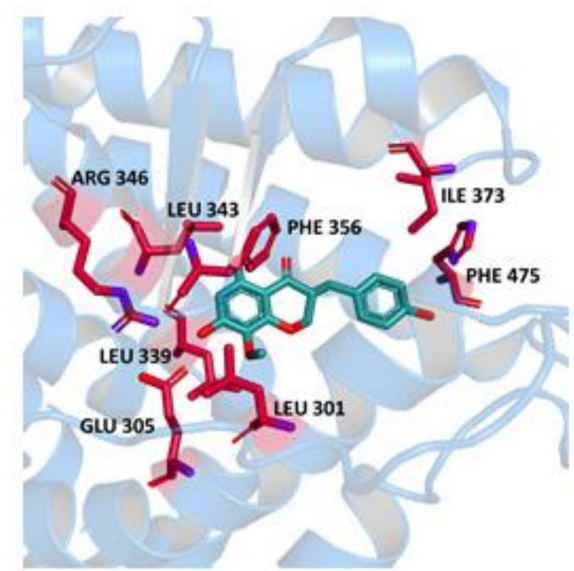

Figure 6. Ligand-binding pocket of the active site of ER $\beta$; ribbons representing protein structural elements are also shown. (A) Superimposed binding modes of all the four ligands: E (yellow), G (magenta), (R)-N1 (green), and (R)-N2 (cyan); the key residues are also indicated in the specific binding mode of (B) E; (C) G; (D) (R)-N1; and (E) (R)-N2. 
Table 1. Binding energies for N1 and N2 in both enantiomeric forms complexed with ER $\alpha$ and ER $\beta$. Docking performed by using AutoDock Vina [31], followed by a minimization refinement for the complex obtained. Results for receptors in dimeric form are reported with two values corresponding to chain A and B, respectively.

\begin{tabular}{cccccc}
\hline \multirow{2}{*}{ PDB Entry } & \multirow{2}{*}{ Receptor } & \multicolumn{4}{c}{ Binding Energy (kcal/mol) } \\
\cline { 3 - 6 } & & $\mathbf{( R ) - N 1}$ & $\mathbf{( S ) - N 1}$ & $\mathbf{( R ) - N 2}$ & (S)-N2 \\
\hline 1A52 & ER $\alpha$ & $-8.4 /-8.5$ & $-8.2 /-8.2$ & $-8.2 /-8.9$ & $-9.2 /-9.3$ \\
1GWR & ER $\alpha$ & $-8.4 /-8.6$ & $-8.3 /-8.5$ & $-8.6 /-8.6$ & $-8.9 /-9.2$ \\
2OCF & ER $\alpha$ & -8.6 & -8.9 & -9.4 & -8.6 \\
2QA8 & ER $\alpha$ & $-8.8 /-9.1$ & $-8.9 /-9.5$ & $-8.8 /-9.0$ & $-8.0 /-8.3$ \\
1X7R & ER $\alpha$ & -9.1 & -8.4 & -8.1 & -8.5 \\
5TOA & ER $\beta$ & $-8.4 /-8.6$ & $-8.2 /-8.4$ & $-8.2 /-8.7$ & $-7.2 /-8.7$ \\
1X7J & ER $\beta$ & $-9.2 /-9.2$ & $-8.4 /-8.9$ & $-8.5 /-8.7$ & $-8.8 /-9.0$ \\
1QKM & ER $\beta$ & -9.2 & -9.0 & -8.8 & -8.8 \\
\hline
\end{tabular}

After assessing the binding of known ligands to the receptors, we proceeded in the estimate of the binding properties of our new compounds. The results of molecular docking performed using the crystallographic structures of the ER $\alpha$ and ER $\beta$ showed in all cases association of the compounds within the same binding sites as E and G. These binding modes were obtained for the ligand docked to rigid receptors, and did not include any re-accommodation of the protein structure. Thus, the complexes obtained were further refined with the same energy-minimization process previously used in the case of the blind docking of the crystallographic ligands. The binding scores found at the end of the refinement procedure are reported in Table 1. The binding energy values were $-8.8 \pm 0.3,-8.6 \pm 0.4,-8.6 \pm 0.4$ and $-8.7 \pm 0.6 \mathrm{kcal} / \mathrm{mol}$ for (R)-N1, (S)-N1, (R)-N2 and (S)-N2, respectively. These values are similar to those obtained in the binding of the crystallographic ligand $\mathrm{G}$, i.e., $-8.9 \pm 0.7$ and $-8.8 \pm 0.3 \mathrm{kcal} / \mathrm{mol}$ in both cases previously discussed (i.e., without or with blind search, respectively). These results strongly suggest that our compounds are able to accommodate in both enantiomeric forms into the active site of ERs with the same affinity of $\mathbf{G}$, and with only a slightly lower affinity compared to $\mathbf{E}$.

Table 2. Binding energies for $E$ and $G$ complexed with ER $\alpha$ and ER $\beta$. Energetic evaluation is performed by using the scoring function of AutoDock Vina [47], either without any search (score-only assessment for the crystallographic poses of the ligands) or exploring the whole receptor (volume-search on the protein structure) followed by a minimization refinement for the complex obtained. Results for receptors in dimeric form are reported with two values corresponding to chain A and B, respectively.

\begin{tabular}{lllll}
\hline \multirow{2}{*}{ Protein Data Bank (PDB) Entry } & \multirow{2}{*}{ Receptor } & Ligand & \multicolumn{2}{l}{ Binding Energy (kcal/mol) } \\
\cline { 5 - 5 } & & & Score-Only & Volume-Search \\
\hline 1A52 & ER $\alpha$ & E & $-9.7 /-9.8$ & $-9.5 /-9.8$ \\
1GWR & ER $\alpha$ & E & $-9.7 /-10.0$ & $-10.3 /-10.1$ \\
2OCF & ER $\alpha$ & E & -9.4 & -9.7 \\
2QA8 & ER $\alpha$ & G & $-8.6 /-9.6$ & $-8.7 /-8.7$ \\
1X7R & ER $\alpha$ & G & -7.8 & -8.5 \\
5TOA & ER $\beta$ & E & $-9.7 /-9.9$ & $-9.5 /-9.5$ \\
1X7J & ER $\beta$ & G & $-9.2 /-8.6$ & $-8.6 /-8.8$ \\
1QKM & ER $\beta$ & G & -9.5 & -9.4 \\
\hline
\end{tabular}

We completed our analysis by investigating the protein residues involved in the ligand-receptor binding within the active site of the two types of receptors in the case of homoisoflavones N1 and N2. Resulting interactions are reported (Table 3) for both the (R) and (S) enantiomers, and are compared with those established by ligands $\mathbf{E}$ and $\mathbf{G}$ in the binding sites of the crystallographic structures. It can be clearly seen that not only the binding energies are similar for the two enantiomers of both N1 and 
N2 (see Table 1), but also the interacting protein residues are the same with only a few exceptions (indicated with the labels ' $(\mathrm{R})^{\prime}$ and '(S)' in Table 3). This observation confirms that our ligands are able to bind both ERs with a larger variety of conformational possibilities compared to $\mathbf{E}$ and $\mathbf{G}$.

Table 3. Key protein residues of estrogen receptors (ERs) interacting with the ligands. Interactions identified with protein-ligand interaction profiler (PLIP) [51]: $\mathrm{HI}=$ hydrophobic interaction; $\mathrm{HB}=$ hydrogen bond; $\pi$-st. $=\pi$-stacking. Interactions with residues in Italics are unique to only one out of the four ligands. (R) or (S) indicate that the interaction in solely formed by either of the two enantiomers of N1/N2.

\begin{tabular}{|c|c|c|c|c|c|c|}
\hline \multirow{3}{*}{ Ligand } & \multicolumn{6}{|c|}{ Interacting Residues } \\
\hline & \multicolumn{3}{|c|}{$\mathrm{ER} \alpha$} & \multicolumn{3}{|c|}{$E R \beta$} \\
\hline & $\mathrm{HI}$ & $\mathrm{HB}$ & $\pi$-st. & $\mathrm{HI}$ & $\mathrm{HB}$ & $\pi$-st. \\
\hline $\mathbf{E}$ & $\begin{array}{l}\text { Leu349 } \\
\text { Ala350 } \\
\text { Leu384 } \\
\text { Leu387 } \\
\text { Leu391 }\end{array}$ & $\begin{array}{l}\text { Leu387 } \\
\text { Arg394 } \\
\text { His524 }\end{array}$ & Phe404 & $\begin{array}{c}\text { Leu298 } \\
\text { Ile373 } \\
\text { Ile376 }\end{array}$ & $\begin{array}{l}\text { Glu305 } \\
\text { Arg346 } \\
\text { His475 }\end{array}$ & Phe356 \\
\hline G & $\begin{array}{c}\text { Leu349 } \\
\text { Leu387 } \\
\text { Leu391 } \\
\text { Ile424 }\end{array}$ & $\begin{array}{l}\text { Ala350 } \\
\text { Leu387 } \\
\text { Arg394 } \\
\text { His524 }\end{array}$ & Phe404 & $\begin{array}{c}\text { Leu339 } \\
\text { Ile373 } \\
\text { Leu476 }\end{array}$ & $\begin{array}{l}\text { Glu305 } \\
\text { Arg346 } \\
\text { His475 }\end{array}$ & Phe356 \\
\hline N1 & $\begin{array}{c}\text { Leu349 (S) } \\
\text { Ala350 (S) } \\
\text { Leu384 } \\
\text { Ile } 424 \\
\text { Leu525 }{ }^{(* 1)} \\
\quad(\mathrm{R})\end{array}$ & $\begin{array}{l}\text { Leu387 } \\
\text { Arg394 } \\
\text { His524 }\end{array}$ & Phe404 & $\begin{array}{c}\text { Leu301 }^{(* 2)} \\
(\mathrm{R}) \\
\text { Leu339 }^{(* 3)} \\
\text { Leu343 }{ }^{(* 3)} \\
\text { Ile373 } \\
\text { His475 }{ }^{(* 4)} \\
(\mathrm{S})\end{array}$ & $\begin{array}{c}\text { Leu298 } \\
\left.\text { Leu339 }{ }^{*}{ }^{* 5}\right) \\
\text { Leu343 }{ }^{(* 3)} \\
\text { Arg346 } \\
\text { His475 }\end{array}$ & Phe356 \\
\hline N2 & $\begin{array}{c}\text { Leu349 (S) } \\
\text { Leu387 } \\
\text { Leu391 } \\
\text { Leu525 }{ }^{(* 1)} \\
(\mathrm{R})\end{array}$ & $\begin{array}{l}\text { Thr347 } \\
\text { Leu387 } \\
\text { Arg394 } \\
\text { His524 }\end{array}$ & Phe404 & $\begin{array}{c}\text { Leu301 }^{(* 2)} \\
\text { Leu339 }\end{array}$ & $\begin{array}{c}\text { Arg346 } \\
\text { Phe356 }{ }^{(* 6)} \\
\text { His475 }\end{array}$ & Phe356 \\
\hline $\begin{array}{l}\left.\text { Notes: }{ }^{*} 1\right) \\
\text { with all th } \\
\text { N1, but for } \\
\text { solely witl }\end{array}$ & $\begin{array}{l}\text { esponds to L } \\
\left.\text { ands; }{ }^{*}{ }^{*}\right) \\
\text { HB with all th } \\
\text { but forms } \mathrm{H}\end{array}$ & $\begin{array}{l}\text { in ER } \beta \text { th } \\
\text { ds to Leu } \\
\text { nds; }{ }^{\left({ }^{*} 5\right)} \text { co } \\
\text { all the lig }\end{array}$ & $\begin{array}{l}\text { Is HI with } \\
\mathrm{ER} \alpha \text { that } \mathrm{f} \\
\text { nds to Leu }\end{array}$ & $\begin{array}{l}\text { 2) correspond } \\
\text { HI with E, G } \\
\text { n ER } \alpha \text { that for }\end{array}$ & $\begin{array}{l}\text { Leu349 in ER } \\
\left.\text { N2; }{ }^{*}{ }^{*}\right) \\
\text { HI worm } \\
\text { with E and }\end{array}$ & $\begin{array}{l}\text { th forms } \mathrm{H} \\
\text { solely wit } \\
\text { 6) forms } \mathrm{H}\end{array}$ \\
\hline
\end{tabular}

Visual inspection provided further details on the binding modes of N1 and N2 within the ERs; due to the similarities of the binding energies and anchoring residues discussed above for their two enantiomers, in the following we will show models representing only the (R) form, although the discussion will regard both forms. In the binding pocket of ER $\alpha$ (Figure 5, Panels A-E), both 17-OH of $\mathbf{E}$ and 7-OH of $\mathbf{G}$ interact with His524 through formation of a hydrogen bond. An equivalent interaction is formed by the phenolic-OH group of N1 and N2. Moreover, 7-OH of N1 and N2 is involved in further hydrogen bonds with Arg394 and Leu387, similarly to the 3-OH of E and the phenolic-OH of $\mathbf{G}$. Additional stabilization of the complex results from a $\pi$-stacking interaction between Phe404 and the aromatic ring of $\mathbf{E}$ or the appended phenyl of $\mathbf{G}$. The same interaction could be established between the aromatic amino acid and the benzo-fused ring of N1 and N2. The ligand-receptor complex is further stabilized for $\mathbf{N} \mathbf{1}$ and $\mathbf{N} \mathbf{2}$ by hydrophobic interactions with Ala350, Ile424, and a number of Leu residues.

In ER $\beta$ (Figure 6), all ligands are involved in a hydrogen bond with His475 and a $\pi$-stacking interaction with Phe356. In particular, an interaction with Hys475 is established by $17-\mathrm{OH}$ of $\mathbf{E}, 7-\mathrm{OH}$ of $\mathrm{G}$ and the phenolic-OH of $\mathbf{N 1}$ and N2. A $\pi$-stacking interaction with Phe356 involves the aromatic ring 
of $\mathbf{E}$ or the appended phenyl of $\mathbf{G}$. Similarly to ER $\alpha$, this interaction is established by the benzo-fused moiety of N1 and N2. For this receptor, a hydrogen bond formation was observed between Arg346 and the 3-OH of $\mathbf{E}$, the phenolic-OH of $\mathbf{G}$, and the 7-OH of $\mathbf{N 1}$ and $\mathbf{N 2}$. The ligand-receptor complex is further stabilized in the presence of N1 and N2 by hydrophobic interactions with Leu301 and Leu339, along with some other interactions specific for each ligand. The presence of the extra carbon atom between the two cyclic portions of the molecule in N1 and N2 is compatible with their accommodation into the active site of both receptors, although the two fused ring systems of N1 and N2 are in a reversed orientation with respect to $\mathbf{G}$.

In summary, our data suggest that the described compounds are sterically compatible and form binding interactions with the key residues of the active site of both ER $\alpha$ and ER $\beta$. It is interesting to note that, besides the conformations of N1 and N2 described above, which closely resemble those of the crystallographic ligand $\mathbf{E}$ and $\mathbf{G}$, we also observed some alternative orientations of our ligands with slightly lower or even comparable energies. This observation is perhaps not surprising, since N1 and N2 possess a larger conformational freedom compared to the structure of both $\mathbf{E}$ and $\mathbf{G}$. Although this possibility does not affect our docking results in terms of binding energy, it could be exploited in the use of these homoisoflavones as leading compounds for further optimization, with the aim of designing ligands with enhanced affinity toward ERs.

\section{Materials and Methods}

\subsection{Plant Material and Phytochemical Profile}

Bulbs of $L$. comosa were collected in the fields of the Sila Massif $\left(39^{\circ} 40^{\prime} 27.34^{\prime \prime} \mathrm{N}, 16^{\circ} 46^{\prime} 79.24^{\prime \prime}\right.$ E-39 $\left.40^{\prime} 9.20^{\prime \prime} \mathrm{N}, 16^{\circ} 46^{\prime} 84.91^{\prime \prime} \mathrm{E}\right)$, Calabria, southern Italy. The bulbs were stored in a cool and dry environment and subsequently separated from roots and cleaned of soil residues. The bulbs (580 g) were used for an extraction with a water/ethanol mixture $(1: 1 \mathrm{v} / \mathrm{v})$ using a Naviglio 囚extractor (Atlas Filtri S.r.L., Limena, PD, Italy) according to previously reported procedures [23]. The total phenol content of the whole extracts was determined using Folin-Ciocalteu reagent and chlorogenic acid as a standard [33]. The total flavonoid content of the crude extract was determined by the $\mathrm{AlCl}_{3}$ colorimetric method on the same extracts used for total phenol determination [34]. The phytochemical composition of the hydroalcoholic extract was investigated by high-performance liquid chromatography coupled to ultraviolet diode array detection (HPLC-UVDAD) and by gas chromatography coupled with mass spectrometric detection (GC-MS) after derivatization (silanization) of the sample as previously described [23].

\subsection{Molecular Docking}

Eight crystallographic structures of ERs [40-46] including five in dimeric form, were obtained from the PDB, and consisted of the protein in complex with either $\mathbf{E}$ or $\mathbf{G}$. The structures of both E and $G$ were extracted from the crystallographic complexes, while the structures of N1 and N2, considered in either $(\mathrm{R})$ or $(\mathrm{S})$ structural conformations, were built by using the modeling software Avogadro [52]. Molecular docking was performed by using AutoDock Vina 1.1.2 (the Scripps Research Institute, La Jolla, CA, USA) [47]. A preliminary conversion of the structures from the PDB format was performed by using the graphical interface AutoDock Tools 1.5.6 (the Scripps Research Institute, La Jolla, CA, USA) [53]. During the conversion, polar hydrogens were added for the crystallographic ligands, and apolar hydrogens of N1 and N2 were merged to the carbon atom they are attached to. To account for the binding in any possible internal pocket of ERs, a search volume including the whole protein was considered, with a grid space of $1 \AA$.

Full flexibility was guaranteed to all the ligands, resulting in two active torsions for $\mathbf{E}$ (the two hydroxyls) and four for $\mathbf{G}$ (three hydroxyls, plus the bond connecting the phenol group to the rest of the molecule). Six rotations around dihedral angles were allowed for both N1 and N2 molecules. A single run was carried out at very high exhaustiveness (16 times larger than the default value) in 
each case. Re-docking experiments were also performed as score-only assessment without any search. Refinement of the complex structures was performed by energy minimization using the web server AMMOS2 [48], which employs the universal force field (UFF) potential set [54] and AMBER partial charges [55] with a conjugate gradient optimization. Intermolecular interactions were evaluated by using the automated protein-ligand interaction profiler (PLIP) [51].

\section{Conclusions}

In this work we have investigated the capability of newly identified homoisoflavones to form complexes with ER proteins. Our results confirm that these compounds are sterically compatible to accommodation within the active site occupied by previously known ligands, E and G, and interact with the same key protein residues of both the isoforms of ERs. Because of the known anti-tumor effect of the parent compound, i.e. the isoflavone $\mathbf{G}$, and due to the possibility of using other natural homoisoflavones or employing these compounds as lead drugs for optimization through a rational design, this study could be considered the starting point for the identification of novel tools in the treatment of estrogen-sensitive breast-cancer. Further studies will be performed successively in order to assess the agonistic or antagonistic activity for these homoisoflavone compounds.

Acknowledgments: B.R. is grateful for the kind hospitality of the Magnetic Resonance Center (CERM), Sesto Fiorentino (Florence), Italy.

Author Contributions: F.Gr. and B.R. conceived and designed the experiments and wrote the manuscript; M.A.O. elaborated and interpreted the molecular docking data; F.Ge. performed and interpreted the spectroscopic data; T.C. and G.I contributed to the analytical tools; A.G, R.G and G.S interpreted data and co-operated in manuscript writing and revision.

Conflicts of Interest: The authors declare no conflict of interest.

\section{References}

1. Wang, P.; McInnes, C.; Zhu, B.T. Structural characterization of the binding interactions of various endogenous estrogen metabolites with human estrogen receptor $\alpha$ and $\beta$ subtypes: A molecular modeling study. PLoS ONE 2013, 8, e74615. [CrossRef] [PubMed]

2. Sukocheva, O.A. Estrogen, estrogen receptors, and hepatocellular carcinoma: Are we there yet? World J. Gastroenterol. 2018, 24, 1-4. [CrossRef] [PubMed]

3. Guillaume, M.; Montagner, A.; Fontaine, C.; Lenfant, F.; Arnal, J.F.; Gourdy, P. Nuclear and membrane actions of estrogen receptor alpha: contribution to the regulation of energy and glucose homeostasis. Adv. Exp. Med. Biol. 2017, 1043, 401-426. [PubMed]

4. Jia, M.; Dahlman-Wright, K.; Gustafsson, J.A. Estrogen receptor alpha and beta in health and disease. Best Pract. Res. Clin. Endoc. Metab. 2015, 29, 557-568. [CrossRef] [PubMed]

5. Pettersson, K.; Delaunay, F.; Gustafsson, J.A. Estrogen receptor beta acts as a dominant regulator of estrogen signaling. Oncogene 2000, 19, 4970-4978. [CrossRef] [PubMed]

6. Paech, K.; Webb, P.; Kuiper, G.G.; Nilsson, S.; Gustafsson, J.; Kushner, P.J.; Scanlan, T.S. Differential ligand activation of estrogen receptors ERalpha and ERbeta at AP1 sites. Science 1997, 277, 1508-1510. [CrossRef] [PubMed]

7. Cowley, S.M.; Parker, M.G. A comparison of transcriptional activation by ER alpha and ER beta. J. Steroid Biochem. Mol. Biol. 1999, 69, 165-175. [CrossRef]

8. Chakraborty, S.; Willett, H.; Biswas, P.K. Insight into estrogen receptor beta-beta and alpha-beta homo- and heterodimerization: A combined molecular dynamics and sequence analysis study. Biophys. Chem. 2012, 170, 42-50. [CrossRef] [PubMed]

9. Farzaneh, S.; Zarghi, A. Estrogen Receptor Ligands: A Review (2013-2015). Sci. Pharm. 2016, 84, 409-427. [CrossRef] [PubMed]

10. Paterni, I.; Granchi, C.; Katzenellenbogen, J.A.; Minutolo, F. Estrogen receptors alpha (ERalpha) and beta (ERbeta): Subtype-selective ligands and clinical potential. Steroids 2014, 90, 13-29. [CrossRef] [PubMed]

11. Kumar, R.; Zakharov, M.N.; Khan, S.H.; Miki, R.; Jang, H.; Toraldo, G.; Singh, R.; Bhasin, S.; Jasuja, R. The dynamic structure of the estrogen receptor. J. Amino Acids 2011, 2011, 812540. [CrossRef] [PubMed] 
12. Traboulsi, T.; El Ezzy, M.; Gleason, J.L.; Mader, S. Antiestrogens: Structure-activity relationships and use in breast cancer treatment. J. Mol. Endocrinol. 2017, 58, R15-R31. [CrossRef] [PubMed]

13. Ascenzi, P.; Bocedi, A.; Marino, M. Structure-function relationship of estrogen receptor alpha and beta: Impact on human health. Mol. Asp. Med. 2006, 27, 299-402. [CrossRef] [PubMed]

14. Huang, B.; Omoto, Y.; Iwase, H.; Yamashita, H.; Toyama, T.; Coombes, R.C.; Filipovic, A.; Warner, M.; Gustafsson, J.A. Differential expression of estrogen receptor $\alpha, \beta 1$, and $\beta 2$ in lobular and ductal breast cancer. Proc. Natl. Acad. Sci. USA 2014, 111, 1933-1938. [CrossRef] [PubMed]

15. Zhao, C.; Lam, E.W.; Sunters, A.; Enmark, E.; de Bella, M.T.; Coombes, R.C.; Gustafsson, J.A.; Dahlman-Wright, K. Expression of estrogen receptor beta isoforms in normal breast epithelial cells and breast cancer: Regulation by methylation. Oncogene 2003, 22, 7600-7606. [CrossRef] [PubMed]

16. Lee, J.Y.; Kim, H.S.; Song, Y.S. Genistein as a potential anticancer agent against ovarian cancer. J. Tradit. Complement. Med. 2012, 2, 96-104. [CrossRef]

17. Zhang, L.L.; Li, L.; Wu, D.P.; Fan, J.H.; Li, X.; Wu, K.J.; Wang, X.Y.; He, D.L. A novel anti-cancer effect of genistein: Reversal of epithelial mesenchymal transition in prostate cancer cells. Acta Pharmacol. Sin. 2008, 29, 1060-1068. [CrossRef] [PubMed]

18. Peterson, G.; Barnes, S. Genistein inhibition of the growth of human breast cancer cells: independence from estrogen receptors and the multi-drug resistance gene. Biochem. Biophys. Res. Commun. 1991, 179, 661-667. [CrossRef]

19. Lentini, F.; Venza, F. Wild food plants of popular use in Sicily. J. Ethnobiol. Ethnomed. 2007, 3, 15. [CrossRef] [PubMed]

20. Pieroni, A.; Nebel, S.; Santoro, R.F.; Heinrich, M. Food for two seasons: culinary uses of non-cultivated local vegetables and mushrooms in a south Italian village. Int. J. Food Sci. Nutr. 2005, 56, 245-272. [CrossRef] [PubMed]

21. Pieroni, A.; Nebel, S.; Quave, C.; Munz, H.; Heinrich, M. Ethnopharmacology of liakra: Traditional weedy vegetables of the Arbereshe of the Vulture area in southern Italy. J. Ethnopharmacol. 2002, 81, 165-185. [CrossRef]

22. Lin, L.G.; Liu, Q.Y.; Ye, Y. Naturally occurring homoisoflavonoids and their pharmacological activities. Planta Med. 2014, 80, 1053-1066. [CrossRef] [PubMed]

23. Casacchia, T.; Scavello, F.; Rocca, C.; Granieri, M.C.; Beretta, G.; Amelio, D.; Gelmini, F.; Spena, A.; Mazza, R.; Toma, C.C.; et al. Leopoldia comosa prevents metabolic disorders in rats with high-fat diet-induced obesity. Eur. J. Nutr. 2018, 1-15. [CrossRef] [PubMed]

24. Nirmal, N.P.; Rajput, M.S.; Prasad, R.G.; Ahmad, M. Brazilin from Caesalpinia sappan heartwood and its pharmacological activities: A review. Asian Pac. J. Trop. Med. 2015, 8, 421-430. [CrossRef] [PubMed]

25. Loizzo, M.R.; Tundis, R.; Menichini, F.; Pugliese, A.; Bonesi, M.; Solimene, U.; Menichini, F. Chelating, antioxidant and hypoglycaemic potential of Muscari comosum (L.) Mill. bulb extracts. Int. J. Food Sci. Nutr. 2010, 61, 780-791. [CrossRef] [PubMed]

26. Dai, Y.; Harinantenaina, L.; Brodie, P.J.; Goetz, M.; Shen, Y.; TenDyke, K.; Kingston, D.G. Antiproliferative homoisoflavonoids and bufatrienolides from Urginea depressa. J. Nat. Prod. 2013, 76, 865-872. [CrossRef] [PubMed]

27. Mulholland, D.A.; Schwikkard, S.L.; Crouch, N.R. The chemistry and biological activity of the Hyacinthaceae. Nat. Prod. Rep. 2013, 30, 1165-1210. [CrossRef] [PubMed]

28. Du Toit, K.; Elgorashi, E.E.; Malan, S.F.; Drewes, S.E.; van Staden, J.; Crouch, N.R.; Mulholland, D.A. Anti-inflammatory activity and QSAR studies of compounds isolated from Hyacinthaceae species and Tachiadenus longiflorus Griseb. (Gentianaceae). Bioorg. Med. Chem. 2005, 13, 2561-2568. [CrossRef] [PubMed]

29. Abegaz, B.M.; Mutanyatta-Comar, J.N. Naturally occurring homoisoflavonoids: Phytochemistry, biological activities and synthesis. Nat. Prod. Commun. 2007, 2, 475-498.

30. Castelli, M.V.; López, S.N. Homoisoflavonoids: Occurrence, biosynthesis, and biological activity. In Studies in Natural Products Chemistry; Elsevier: Amsterdam, Netherlands, 2017; Volume 54, pp. 315-354.

31. Mann, J.; Davidson, R.S.; Hobbs, J.B.; Banthorpe, D.V.; Harbome, J.B. Natural products: Their chemistry and biological significance. In Longman Scientific and Technical; Harlow, E., Ed.; Longman Group UK Ltd.: Harlow, UK, 1994; p. 372. 
32. De Vincenzi, S.; Lupattelli, M.; Cestola, E.; Liponi, G.B. Effect of variety and agronomical conditions on the level of polyphenols and antinutritional factors of Vicia Faba Minor. Vet. Res. Commun. 2006, 30, 371-374. [CrossRef]

33. Casacchia, T.; Sofo, A.; Casaburi, I.; Marrelli, M.; Conforti, F.; Statti, G.A. Antioxidant, enzyme-inhibitory and antitumor activity of the wild dietary plant Muscari comosum (L.). Int. J. Plant Biol. 2017, 8, 6895. [CrossRef]

34. Marrelli, M.; Cristaldi, B.; Menichini, F.; Conforti, F. Inhibitory effects of wild dietary plants on lipid peroxidation and on the proliferation of human cancer cells. Food Chem. Toxicol. 2015, 86, 16-24. [CrossRef] [PubMed]

35. Martinez-Archundia, M.; Garcia-Vazquez, J.B.; Colin-Astudillo, B.; Bello, M.; Prestegui-Martel, B.; Chavez-Blanco, A.; Duenas-Gonzalez, A.; Fragoso-Vazquez, M.J.; Mendieta-Wejebe, J.; Abarca-Rojano, E.; et al. Computational study of the binding modes of diverse DPN analogues on estrogen receptors (ER) and the biological evaluation of a new potential antiestrogenic ligand. Anticancer Agents Med. Chem. 2018. [CrossRef] [PubMed]

36. Yugandhar, P.; Kumar, K.K.; Neeraja, P.; Savithramma, N. Isolation, characterization and in silico docking studies of synergistic estrogen receptor a anticancer polyphenols from Syzygium alternifolium (Wt.) Walp. J. Intercult. Ethnopharmacol. 2017, 6, 296-310. [CrossRef] [PubMed]

37. Muchtaridi, M.; Syahidah, H.N.; Subarnas, A.; Yusuf, M.; Bryant, S.D.; Langer, T. Molecular docking and 3D-pharmacophore modeling to study the interactions of chalcone derivatives with estrogen receptor alpha. Pharmaceuticals 2017, 10, 81. [CrossRef] [PubMed]

38. Manas, E.S.; Unwalla, R.J.; Xu, Z.B.; Malamas, M.S.; Miller, C.P.; Harris, H.A.; Hsiao, C.; Akopian, T.; Hum, W.T.; Malakian, K.; et al. Structure-based design of estrogen receptor-beta selective ligands. J. Am. Chem. Soc. 2004, 126, 15106-15119. [CrossRef] [PubMed]

39. Berman, H.M.; Westbrook, J.; Feng, Z.; Gilliland, G.; Bhat, T.N.; Weissig, H.; Shindyalov, I.N.; Bourne, P.E. The Protein Data Bank. Nucleic Acids Res. 2000, 28, 235-242. [CrossRef] [PubMed]

40. Manas, E.S.; Xu, Z.B.; Unwalla, R.J.; Somers, W.S. Understanding the selectivity of genistein for human estrogen receptor-beta using X-ray crystallography and computational methods. Structure 2004, 12, 2197-2207. [CrossRef] [PubMed]

41. Koide, A.; Abbatiello, S.; Rothgery, L.; Koide, S. Probing protein conformational changes in living cells by using designer binding proteins: application to the estrogen receptor. Proc. Natl. Acad. Sci. USA 2002, 99, 1253-1258. [CrossRef] [PubMed]

42. Pike, A.C.; Brzozowski, A.M.; Hubbard, R.E.; Bonn, T.; Thorsell, A.G.; Engstrom, O.; Ljunggren, J.; Gustafsson, J.A.; Carlquist, M. Structure of the ligand-binding domain of oestrogen receptor beta in the presence of a partial agonist and a full antagonist. Embo J. 1999, 18, 4608-4618. [CrossRef] [PubMed]

43. Nettles, K.W.; Bruning, J.B.; Gil, G.; Nowak, J.; Sharma, S.K.; Hahm, J.B.; Kulp, K.; Hochberg, R.B.; Zhou, H.; Katzenellenbogen, J.A.; et al. NFkB selectivity of estrogen receptor ligands revealed by comparative crystallographic analyses. Nat. Chem. Biol. 2008, 4, 241-247. [CrossRef] [PubMed]

44. Tanenbaum, D.M.; Wang, Y.; Williams, S.P.; Sigler, P.B. Crystallographic comparison of the estrogen and progesterone receptor's ligand binding domains. Proc. Natl. Acad. Sci. USA 1998, 95, 5998-6003. [CrossRef] [PubMed]

45. Warnmark, A.; Treuter, E.; Gustafsson, J.A.; Hubbard, R.E.; Brzozowski, A.M.; Pike, A.C. Interaction of transcriptional intermediary factor 2 nuclear receptor box peptides with the coactivator binding site of estrogen receptor alpha. J. Biol. Chem. 2002, 277, 21862-21868. [CrossRef] [PubMed]

46. Souza, P.C.T.; Textor, L.C.; Melo, D.C.; Nascimento, A.S.; Skaf, M.S.; Polikarpov, I. An alternative conformation of ERbeta bound to estradiol reveals H12 in a stable antagonist position. Sci. Rep. 2017, 7, 3509. [CrossRef] [PubMed]

47. Trott, O.; Olson, A.J. AutoDock Vina: Improving the speed and accuracy of docking with a new scoring function, efficient optimization, and multithreading. J. Comput. Chem. 2010, 31, 455-461. [CrossRef] [PubMed]

48. Labbè, C.M.; Pencheva, T.; Jereva, D.; Desvillechabrol, D.; Becot, J.; Villoutreix, B.O.; Pajeva, I.; Miteva, M.A. AMMOS2: A web server for protein-ligand-water complexes refinement via molecular mechanics. Nucleic Acids Res. 2017, 45, W350-W355. [CrossRef] [PubMed]

49. Summa, C.M.; Levitt, M. Near-native structure refinement using in vacuo energy minimization. Proc. Natl. Acad. Sci. USA 2007, 104, 3177-3182. [CrossRef] [PubMed] 
50. Rizzuti, B.; Daggett, V. Using simulations to provide the framework for experimental protein folding studies. Arch. Biochem. Biophys. 2013, 531, 128-135. [CrossRef] [PubMed]

51. Salentin, S.; Schreiber, S.; Haupt, V.J.; Adasme, M.F.; Schroeder, M. PLIP: Fully automated protein-ligand interaction profiler. Nucleic Acids Res. 2015, 43, W443-W447. [CrossRef] [PubMed]

52. Hanwell, M.D.; Curtis, D.E.; Lonie, D.C.; Vandermeersch, T.; Zurek, E.; Hutchison, G.R. Avogadro: An advanced semantic chemical editor, visualization, and analysis platform. J. Cheminform. 2012, 4, 17. [CrossRef] [PubMed]

53. Morris, G.M.; Goodsell, D.S.; Halliday, R.S.; Huey, R.; Hart, W.E.; Belew, R.K.; Olson, A.J. Automated docking using a Lamarckian genetic algorithm and an empirical binding free energy function. J. Comput. Chem. 1998, 19, 1639-1662. [CrossRef]

54. Rappé, A.K.; Casewit, C.J.; Colwell, K.S.; Goddard, W.A. UFF, a full periodic table force field for molecular mechanics and molecular dynamics simulations. J. Am. Chem. Soc. 1992, 114, 10024-10035. [CrossRef]

55. Weiner, S.J.; Kollman, P.A.; Nguyen, D.T.; Case, D.A. An all atom force field for simulations of proteins and nucleic acids. J. Comput. Chem. 1986, 7, 230-252. [CrossRef] [PubMed]

Sample Availability: Samples of the compounds are not available from the authors. 